\title{
Keragaman dan Penyebaran Benalu pada Tanaman Koleksi di Kebun Raya Cibodas, Jawa Barat
}

\author{
Diversity and Distribution of Mistletoe on Plant Collections in Cibodas Botanical \\ Gardens, West Java
}

Tahan Uji* dan Sunaryo

Bidang Botani, Pusat Penelitian Biologi, LIPI, Jl. Raya Jakarta-Bogor Km 46 Cibinong 16911

E-mail: herbogor@indo.net.id *Penulis untuk korespondensi

\begin{abstract}
A study on mistletoe has been carried out in Cibodas Botanical Garden,West Java. The aim of the study were to know mistletoe diversity which have attacked many collection plants species in the area. Result of the study indicated that there were 5 species mistletoe (i.e. Dendrophthoe pentandra, Scurrula oortiana, Macrosolen cochinchinensis, Lepeostegeres gemmiflorus and Viscum articulatum) and they attacked 91 collection plants species in Cibodas Botanical Garden. D. pentandra was reported as the most abudance mistletoe. Collection plants species of familes Moraceae and Myrtaceae were also reported as the highest of collection plants species have been parasited by mistletoe.
\end{abstract}

Key words: mistletoe, diversity, Cibodas Botanic Garden, West Java

Diterima: 08 Maret 2008, disetujui: 05 Juni 2008

\section{Pendahuluan}

Benalu merupakan tumbuhan parasit yang dapat menyerang tanaman budidaya maupun tumbuhan liar. Umumnya yang diserang adalah berupa pohon ataupun perdu. Serangan benalu dapat mengakibatkan terganggunya pertumbuhan bahkan kematian inangnya apabila serangan tersebut dalam jumlah besar (Sunaryo et al., 2006).

Kelompok jenis tumbuhan benalu termasuk dalam suku Loranthaceae dan Viscaceae. Suku Loranthaceae terdiri atas 65 marga meliputi 950 jenis yang sebagian besar tumbuh di kawasan tropis dan sebagian kecil lainnya di kawasan beriklim sedang. Suku Viscaceae hanya terdiri atas 7 marga meliputi 400 jenis yang mayoritas tumbuh di kawasan tropis, dan hanya beberapa jenis di kawasan beriklim sedang. Di kawasan Malesia dilaporkan bahwa suku Loranthaceae mempunyai 23 marga dan 193 jenis, sedangkan suku Viscaceae hanya dengan 4 marga dan 26 jenis (Barlow, 1967).
Di Jawa, suku Loranthaceae (termasuk Viscaceae) hanya dapat ditemukan 37 jenis tergolong dalam 14 marga. Di Jawa Barat ditemukan 28 jenis benalu dan 22 jenis diantaranya dapat tumbuh di atas ketinggian $>$ $1300 \mathrm{~m}$ di atas permukaan laut (Backer dan van den Brink, 1965).

Kebun Raya Cibodas merupakan salah satu Kebun Raya di Indonesia yang dirancang untuk penanaman koleksi tumbuhan dari dataran tinggi yang beriklim basah. Kebun Raya ini terletak di lereng Gunung GedePangrango pada ketinggian $1.425 \mathrm{~m}$ di atas permukaan laut. Luasnya mencapai 125 hektar dan $30 \%$ diantaranya merupakan area yang dihutankan. Jumlah tanaman koleksinya mencapai 1189 jenis terdiri atas 183 suku dan 622 marga (Immamudin et al., 2005). Dalam usaha menjaga kelestarian tanaman koleksi di Kebun Raya Cibodas dilakukan perawatan tanaman, salah satunya adalah pengendalian dari serangan tumbuhan benalu. Sampai saat ini belum pernah dilakukan identifikasi terhadap 
jenis-jenis benalu pada tanaman koleksi di Kebun Raya Cibodas.

Penelitian benalu ini merupakan lanjutan dari penelitian sebelumnya yang telah dilakukan di Kebun Raya Purwodadi, Jawa Timur pada tahun 2005 dan di Kebun Raya Eka Karya Bali pada tahun 2006 (Uji et al., 2007). Tujuannya antara lain untuk menyediakan data atau informasi terhadap jenis-jenis benalu yang menyerang tanaman koleksi di Kebun Raya Cibodas dan membantu cara pengenalan jenisjenis benalu di lapangan.

\section{Metode Penelitian}

Penelitian dilakukan dengan metode jelajah (Balgooy, 1987; Rugayah et al., 2004) yaitu dengan cara menjelajahi setiap lokasi yang ditemukan adanya benalu pada tanamantanaman koleksi di Kebun Raya Cibodas. Setiap jenis benalu yang ditemukan tumbuh pada tanaman koleksi dicatat data morfologi dan dibuat spesimen herbariumnya. Selain itu juga dilakukan pencatatan jumlah individu pada masing-masing jenis benalu untuk setiap jenis tanaman koleksi/inang yang diserang benalu di Kebun Raya Cibodas. Identifikasi jenis benalu dilakukan di Herbarium Bogoriense dengan cara membandingkan dengan koleksi yang ada. Untuk validasi dalam identifikasi jenis-jenis benalu digunakan beberapa buku acuan antara lain Danser (1930), Backer dan van den Brink (1965) dan Barlow (1967).

\section{Hasil dan Pembahasan}

Penelitian ini menemukan 5 jenis benalu yang tumbuh pada 91 jenis tanaman koleksi dari 41 suku di Kebun Raya Cibodas (Tabel 1). Dendrophthoe pentandra merupakan jenis benalu yang paling banyak ditemukan hidup di tanaman koleksi. Tercatat 66 jenis dari 35 suku tanaman koleksi telah diparasiti $D$. pentandra. Peringkat selanjutnya disusul oleh Scurrula oortiana yang menyerang 48 jenis dari 25 suku dan Macrosolen cochinchinensis menyerang 15 jenis dari 11 suku tanaman koleksi. Sedangkan Lepeostegeres gemmiflorus tercatat yang paling sedikit yaitu hanya menyerang 3 jenis dari 3 suku tanaman koleksi di Kebun Raya Cibodas.

D. pentandra juga telah dilaporkan sebagai salah satu jenis benalu parasit yang paling banyak menyerang tanaman koleksi di Kebun Raya Purwodadi, Jawa Timur, dan di Kebun Raya Ekakarya Bali (Uji et al., 2006; Uji et al., 2007). Hal ini menunjukkan bahwa D. pentandra merupakan salah satu jenis benalu yang mempunyai agresivitas penyerangan yang paling tinggi dibandingkan dengan jenis-jenis benalu lainnya. Berbeda dengan $L$. gemmiflorus yang agresivitas serangannya adalah yang paling rendah, dan dilaporkan sebagai satu-satunya benalu yang endemik karena hanya dapat ditemukan di Jawa bagian barat (Barlow, 1967).

Penyebaran setiap jenis benalu dilakukan melalui burung-burung pemakan buahnya. Penyebaran biji-biji benalu sampai saat ini dilakukan oleh burung-burung yang termasuk dalam suku Dicacidae (Van Leeuwen, 1954), khususnya Dicaeum spp./burung cabe (Pitojo, 1996). Penyebarannya terjadi dari satu jenis inang ke jenis inang yang lain dan sangat terbantu oleh sifat biji-bijinya yang lengket berlendir karena mengandung 'viscin'.

\section{Jenis-jenis benalu dan tanaman inangnya}

Pada Tabel 1 tercatat bahwa jenis-jenis tanaman koleksi/inang di Kebun Raya Cibodas yang paling banyak diparasiti benalu adalah dari suku Moraceae (10 jenis), dan Myrtaceae (9 jenis). Khususnya untuk suku Moraceae, tercatat 9 jenis diantaranya adalah dari marga Ficus. Hal ini juga ditemukan di Kebun Raya Purwodadi, dimana tercatat bahwa jenis-jenis tanaman koleksi yang paling banyak diparasiti benalu di kebun raya ini juga dari suku Moraceae terutama dari marga Ficus (Uji et al., 2006). Disamping itu dilaporkan pula bahwa di Kebun Raya Ekakarya di Bali, jenis-jenis tanaman koleksinya yang paling banyak diparasiti benalu juga dari suku Myrtaceae (Uji et al., 2007). Ini menunjukkan bahwa jenisjenis tanaman suku Moraceae dan Myrtaceae merupakan jenis-jenis tanaman yang paling banyak diserang benalu. Dugaan sementara bahwa jenis-jenis Ficus (suku Moraceae) disukai oleh benalu karena memiliki kulit cabang/ranting yang tipis ataupun lunak. Kulit 
cabang/ranting tumbuhan inang yang tipis akan lebih membantu benalu pada awal-awal pertumbuhannya, sampai parasit ini mampu untuk menginvasi bagian kayu yang lebih dalam dimana terdapat berkas-berkas pengangkut.

Kecepatan perkecambahan benalu untuk mencapai berkas-berkas pengangkut pada tumbuhan inang sangat diperlukan, sebelum cadangan makanan yang terdapat didalam biji benalu habis. Sementara itu kulit cabang/ranting yang tebal dan keras (misalnya jenis mahoni) akan menghambat secara fisik bagi pertumbuhan awal benalu, sehingga cadangan makanan yang tersedia terbongkar habis sebelum haustorium sebagai alat kontak benalu berhasil mencapai bagian-bagian kayu yang mengandung berkas-berkas pengangkut. Kontak antara benalu dengan berkas-berkas pengangkut pada tumbuhan inang sangat diperlukan bagi pertumbuhan benalu lebih lanjut.

Dari 91 jenis tanaman koleksi di Kebun Raya Cibodas, Melicope decandra (Rutaceae) dan Callistemon citrinus (Myrtaceae) adalah jenis-jenis tanaman koleksi yang paling banyak diparasiti oleh $D$. pentandra. Tercatat untuk masing-masing jenis tanaman koleksi tersebut telah diparasiti oleh 15 tumbuhan benalu (Tabel
1). Selain itu juga Acronychia laurifolia (Rutaceae) dan Diospyros kaki (Ebenaceae) masing-masing juga telah diparasiti oleh 14 tumbuhan benalu dari $D$. pentandra. Sedangkan untuk jenis benalu S. oortiana, serangan terbesarnya ditemukan pada koleksi Ligustrum japonicum (Oleaceae) ditemukan 15 tumbuhan benalu dari $D$. pentandra. Selanjutnya pada Saurauia javanica (Actinidiaceae) dan Villebrunea scabra (Urticaceae) masing-masing dengan 14 tumbuhan benalu $D$. pentandra. Hal ini menunjukkan bahwa Melicope decandra, Acronychia laurifolia, Callistemon citrinus, dan Diospyros kaki merupakan jenis-jenis tanaman inang yang paling disukai oleh $D$. pentandra. Berbeda dengan S. oortiana, jenis benalu ini lebih menyukai pada Ligustrum javanicum, Saurauia javanica, dan Villebrunea decandra sebagai tanaman inangnya.

Viscum articulatum merupakan satusatunya dari 5 jenis benalu di Kebun Raya Cibodas yang mempunyai sifat parasit yang berbeda. Jenis benalu ini dilaporkan sebagai tumbuhan parasit yang memarasiti jenis benalu parasit lainnya (Barlow, 1967). Di Kebun Raya Cibodas, V. articulatum ditemukan tumbuh memarasiti $D$. pentandra dan $M$. cochinchinensis.

Tabel 1. Daftar jenis tanaman koleksi/inang di Kebun Raya Cibodas yang diparasiti benalu dan jenis-jenis benalu serta jumlah benalu parasitnya.

\begin{tabular}{|c|c|c|c|}
\hline No. & Nama Suku dan Jenis Tanaman Inang & Nama Jenis Benalu & Jumlah Benalu \\
\hline & ACTINIDIACEAE & & \\
\hline 1. & $\begin{array}{l}\text { Saurauia javanica (Nees.) Hoogl. } \\
\text { ALANGIACEAE }\end{array}$ & II & 14 \\
\hline 2. & $\begin{array}{l}\text { Alangium chinensis (Lour.) Rehder } \\
\text { ANACARDIACEAE }\end{array}$ & II & 1 \\
\hline 3. & Rhus succedanea L. & I & 5 \\
\hline 4. & Schinus lentiscifolius March. & II & 3 \\
\hline 5. & $\begin{array}{l}\text { S. terebinthifolius Raddi } \\
\text { ANNONACEAE }\end{array}$ & I, III & 11,5 \\
\hline 6. & $\begin{array}{l}\text { Orophea hexandra Blume } \\
\text { APOCYNACEAE }\end{array}$ & I & 3 \\
\hline 7. & $\begin{array}{l}\text { Rauvolfia javanica Koord. \& Val. } \\
\text { ARAUCARIACEAE }\end{array}$ & I & 4 \\
\hline 8. & $\begin{array}{l}\text { Araucaria bidwillii Hook. } \\
\text { BIGNONIACEAE }\end{array}$ & I & 1 \\
\hline 9. & Parmentiera cerifera Seemann & II & 1 \\
\hline 10. & $\begin{array}{l}\text { Texoma hypoleuca Wright } \\
\text { BORAGINACEAE }\end{array}$ & II & 11 \\
\hline 11. & Erehtia javanica Blume & I, V & 3,1 \\
\hline
\end{tabular}


Tabel 1. (lanjutan)

\begin{tabular}{|c|c|c|c|}
\hline & CAPRIFOLIACEAE & & \\
\hline 12. & Vibrunum sambucinum Reinw. Ex Blume & II & 1 \\
\hline 13. & V. suspensum Lindley & II & 2 \\
\hline & CASUARINACEAE & & \\
\hline 14. & $\begin{array}{l}\text { Casuarina junghuhniana Miq. } \\
\text { CORNACEAE }\end{array}$ & I, II, III & $2,1,4$ \\
\hline 15. & $\begin{array}{l}\text { Cornus capitata Wall. } \\
\text { DILLENIACEAE }\end{array}$ & I & 1 \\
\hline 16. & $\begin{array}{l}\text { Dillenia philippinensis Rolfe } \\
\text { EBENACEAE }\end{array}$ & I & 5 \\
\hline 17. & $\begin{array}{l}\text { Diospyros kaki Thunb. } \\
\text { ELAEOCARPACEAE }\end{array}$ & I, II, IV & $14,1,2$ \\
\hline 18. & $\begin{array}{l}\text { Elaeocarpus oxypyren Koord. } \\
\text { ERICACEAE }\end{array}$ & I & 2 \\
\hline 19. & $\begin{array}{l}\text { Rhododendron mucronatum (Blume) G. Don. } \\
\text { EUPHORBIACEAE }\end{array}$ & I, II & 1,2 \\
\hline 20. & Acalypha wilkesiana Muell. Arg. & I, II & 3,2 \\
\hline 21. & Bridelia insulana Hance & II & 3 \\
\hline 22. & $\begin{array}{l}\text { Breynia microphylla (Kurz. ex Tiejsm.\& Binn.) } \\
\text { Muell.Arg }\end{array}$ & II & 1 \\
\hline 23. & $\begin{array}{l}\text { Glochidion macrocarpum Blume } \\
\text { FAGACEAE }\end{array}$ & II & 1 \\
\hline 24. & $\begin{array}{l}\text { Quercus myrsinaefolia Blume } \\
\text { HAMAMELIDACEAE }\end{array}$ & I & 4 \\
\hline 25. & Altingia excelsa Noronha & I, V & 5,1 \\
\hline 26. & $\begin{array}{l}\text { Liquidambar formosana Hance } \\
\text { LAURACEAE }\end{array}$ & I & 4 \\
\hline 27. & Cinnamomum burmanii Nees. Ex Blume & III, V & 6,1 \\
\hline 28. & C. camphora (L.) Presl. & I, II & 2,1 \\
\hline 29. & Cryptocarya ferrea Blume & I & 3 \\
\hline 30. & $\begin{array}{l}\text { Persea americana Miller } \\
\text { LYTHRACEAE }\end{array}$ & II & 8 \\
\hline 31. & $\begin{array}{l}\text { Lagerstroemia indica L. } \\
\text { MAGNOLIACEAE }\end{array}$ & I, II & 5,3 \\
\hline 32. & Magnolia grandiflora L. var. lanceolata W.T.Ait. & I, II, V & $3,2,1$ \\
\hline 33. & M. grandiflora L. & I, II, III & $3,2,2$ \\
\hline 34. & M. liliflora Desr. & II, III & 2,1 \\
\hline 35. & Manglitea glauca Blume & I & 5 \\
\hline 36. & $\begin{array}{l}\text { Michelia montana Blume } \\
\text { MIMOSACEAE }\end{array}$ & I & 1 \\
\hline 37. & Acacia melanoxylon R.Br. & I, II & 2,1 \\
\hline 38. & Calliandra haematocephala Hassk. & I & 5 \\
\hline 39. & $\begin{array}{l}\text { Calliandra calothyrsus Meisn. } \\
\text { MORACEAE }\end{array}$ & I, II & 3,3 \\
\hline 40. & Ficus benyamina L. & III & 1 \\
\hline 41. & F. fistulosa Reinw. ex Blume & II & 12 \\
\hline 42. & F. ribes Reinw. ex Blume & I, II & 4,7 \\
\hline 43. & F. rubra Vahl. & I & 1 \\
\hline 44. & F. septica Burm.f & II & 7 \\
\hline 45. & F. variegata Blume & I & 4 \\
\hline 46. & F. sinuata Thunb. ssp.cuspidata (Reinw.ex Bl.) Corner & II, III & 1,2 \\
\hline 47. & F. obscura Blume & I, II & 5,11 \\
\hline 48. & F. grossularoides Burm. f. & I, II & 1,1 \\
\hline 49. & Morus nigra L. & I & 3 \\
\hline
\end{tabular}


Tabel 1. (lanjutan)

\begin{tabular}{|c|c|c|c|}
\hline 50. & $\begin{array}{l}\text { MYRICACEAE } \\
\text { Myrica rubra Sieb. \& Zucc. } \\
\text { MYRTACEAE }\end{array}$ & I, II, V & $11,1,2$ \\
\hline 51. & Callistemon citrinus (Curtis) Stapf. & I, II, V & $15,10,1$ \\
\hline 52. & C. polandi F.M. Bailey & I, II & 8, 3 \\
\hline 53. & Eugenia arnottiana Wight. & I & 3 \\
\hline 54. & Leptospermum citratum Challinor & I & 7 \\
\hline 55. & Melaleuca genistifolia Smith & I & 1 \\
\hline 56. & M. linariifolia Sm. var. trichystachys & I, II & 2,2 \\
\hline 57. & Syzygium equeum Alston & I & 5 \\
\hline 58. & S. pycnanthum Merr. \& Perry & I & 1 \\
\hline 59. & $\begin{array}{l}\text { S. racemosum (Blume) DC. } \\
\text { OLEACEAE }\end{array}$ & I & 3 \\
\hline 60. & Ligustrum japonicum Thunb. & II & 15 \\
\hline 61. & $\begin{array}{l}\text { L. lucidum W.T. Aiton } \\
\text { PAPILIONACEAE }\end{array}$ & I, II & 1,4 \\
\hline 62. & Erythrina guatemalensis Krukoff & I & 1 \\
\hline 63. & E. chiapasana Krukoff & I & 3 \\
\hline 64. & $\begin{array}{l}\text { Gleditsia sinensis Lamk } \\
\text { PINACEAE }\end{array}$ & I & 4 \\
\hline 65. & $\begin{array}{l}\text { Pinus parviflora Sieber \& Zucc. } \\
\text { PROTEACEAE }\end{array}$ & I & 1 \\
\hline 66. & $\begin{array}{l}\text { Macadamia ternifolia F.Muell. cv. Kokensos } \\
\text { ROSACEAE }\end{array}$ & I & 5 \\
\hline 67. & Cotoneaster panuosa Franch. & II & 1 \\
\hline 68. & Crataegus pyracantha Medic. & I, III, IV & 7,91 \\
\hline 69. & Eriobotrya japonica (Thunb.) Lindl. & II & 1 \\
\hline 70. & Prunus cerasoides D.Don. & I, II & 1,1 \\
\hline 71. & Poterium sanguisorba L. subsp. polyama & I & 2 \\
\hline 72. & Pyracantha crenato-serrata (Hance) Rehder & I, II & 4,2 \\
\hline 73. & P. fortuneana (Maxim) Lig & I, II, III & $3,4,2$ \\
\hline 74. & $\begin{array}{l}\text { Raphiolepis indica (L.) Lindl. ex Ker. } \\
\text { RUBIACEAE }\end{array}$ & I & 4 \\
\hline 75. & Hamelia sphaerocarpa Ruiz \& Pavon & I, III & 2,6 \\
\hline 76. & $\begin{array}{l}\text { Neonauclea lanceolata (Blume) Merr. } \\
\text { RUTACEAE }\end{array}$ & I & 1 \\
\hline 77. & Acronychia laurifolia Blume & I & 14 \\
\hline 78. & Citrus grandis (L.) Osbeck. & I, II & 4,5 \\
\hline 79. & C. medica L. & II & 1 \\
\hline 80. & $\begin{array}{l}\text { Melicope denhamii (Seem.) T.G.Hartley } \\
\text { SALIXACEAE }\end{array}$ & I, II, III, IV & $15,4,7,1$ \\
\hline 81. & $\begin{array}{l}\text { Salix babylonica L. } \\
\text { SCROPHULARIACEAE }\end{array}$ & I, II, III & $4,7,1$ \\
\hline 82. & $\begin{array}{l}\text { Panlowniana taiwaniana T.W.Hu \& H.J. Chang } \\
\text { SOLANACEAE }\end{array}$ & I & 1 \\
\hline 83. & $\begin{array}{l}\text { Brunfelsia australis Benth. } \\
\text { STERCULIACEAE }\end{array}$ & I & 7 \\
\hline 84. & $\begin{array}{l}\text { Pterospermum javanicum Junghuhn } \\
\text { SYMPLOCACEAE }\end{array}$ & I, V & 3,1 \\
\hline 85. & Symplocos cochinchinensis (Lour.) S.Moore & II & 7 \\
\hline 86. & $\begin{array}{l}\text { S. fasciculata Zoll. } \\
\text { TAXODIACEAE }\end{array}$ & II & 7 \\
\hline $\begin{array}{l}87 . \\
88 .\end{array}$ & $\begin{array}{l}\text { Cryptomeria japonica (L.) D. Don. } \\
\text { Taxodium mucronatum Ten. }\end{array}$ & $\begin{array}{c}\text { I, III } \\
\text { I, II, III }\end{array}$ & $\begin{array}{c}6,3 \\
1,3,1\end{array}$ \\
\hline
\end{tabular}


Tabel 1. (lanjutan)

\begin{tabular}{|c|c|c|c|}
\hline & THEACEAE & & \\
\hline 89. & Camellia japonica L. & II & 1 \\
\hline 90. & C. japonica L. cv. Hana-Guruma & I, II & 1,1 \\
\hline 91. & $\begin{array}{l}\text { Pyrenaria serrata Blume } \\
\text { ULMACEAE }\end{array}$ & II & 1 \\
\hline 92. & $\begin{array}{l}\text { Celtis sinensis Pers. } \\
\text { URTICACEAE }\end{array}$ & I, III & 1,1 \\
\hline 93. & Villebrunea scabra Wedd. & I, II & 2,14 \\
\hline
\end{tabular}

Keterangan: I = Dendrophthoe pentandra (L.) Miq.

II = Scurrula oortiana (Korth.) Dans.

III = Macrosolen cochinchinensis (Lour.) Tiegh.

$\mathrm{IV}=$ Lepeostegeres gemmiflorus (Blume) Blume

$\mathrm{V}=$ Viscum articulatum Burm. $\mathrm{f}$.

\section{Pengenalan jenis tumbuhan benalu}

Lima jenis benalu yang ditemukan di Kebun Raya Cibodas (Gambar 1) terdiri atas 2 suku, yaitu suku Loranthaceae dan Viscaceae. Suku Loranthaceae terdiri atas 4 jenis: Dendrophthoe pentandra (L.) Miq; Scurrula oortiana (Korth.) Dans; Macrosolen cochinchinensis (Lour.) Tiegh; Lepeostegeres gemmiflorus (Blume) Blume.

Sedangkan suku Viscaceae hanya 1 jenis, yaitu: Viscum articulatum Burm. f.

Berikut adalah kunci identifikasi untuk membedakan suku Loranthaceae dan Viscaceae.

1.a Bunga biseksual, perhiasan bunga diklamid. Buah mempunyai lapisan lekat yang terdapat di luar berkas pembuluh .Loranthaceae

1.b Bunga uniseksual, perhiasan bunga monoklamid. Buah mempunyai lapisan lekat yang terdapat di dalam berkas pembuluh ..Viscaceae

\section{Diskripsi suku tumbuhan benalu}

\section{Loranthaceae}

Hemiparasit, melekat pada tumbuhan inang dengan haustoria yang banyak atau merupakan komplek haustoria primer tunggal. Daun kebanyakan berhadapan dan kadangkadang berseling, tunggal. Perbungaan pada umumnya aksiler jarang sekali terminal, dikasium atau bunga tunggal, biasanya mengelompok membentuk tandan atau payung. Bunga diklamid, biseksual. Kelopak bunga merupakan bibir menyelaput di ujung bakal buah. Mahkota bunga koripetalus atau gamopetalus, 4 - 6 merus, mengatup. Benang sari sama banyaknya dengan daun mahkota dan terletak saling berhadapan, epipetalus. Bakal buah tenggelam, tangkai putik dan kepala putik tunggal. Buah menyerupai beri. Biji satu dikelilingi lapisan lekat di luar berkas pengangkutan.

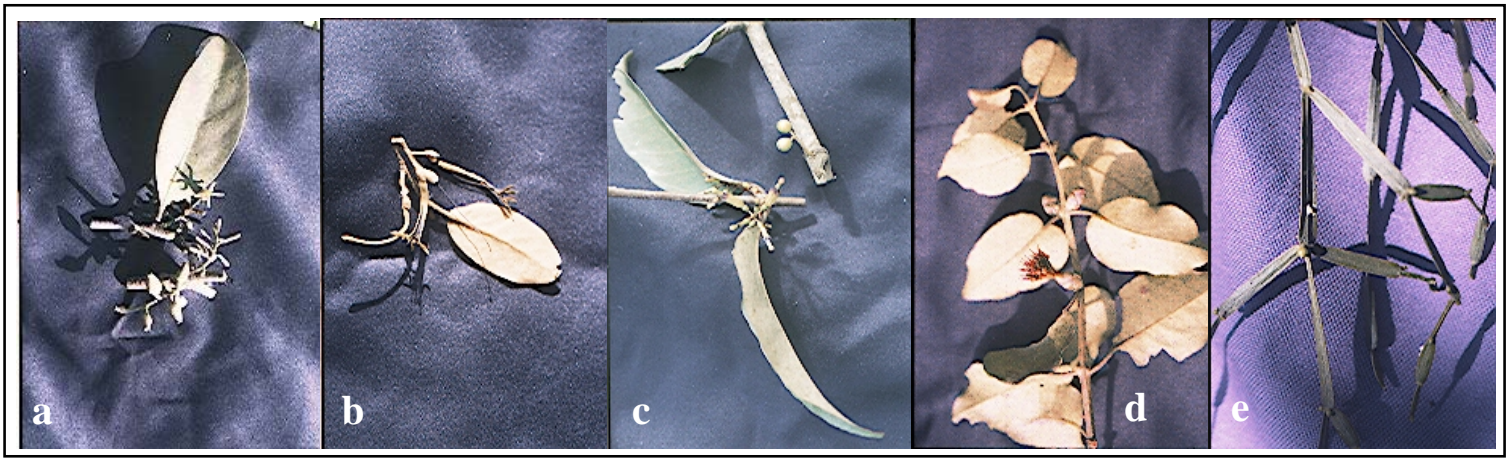

Gambar 1. Jenis-jenis benalu di Kebun Raya Cibodas, Jawa Barat.

Keterangan: $\mathrm{a}=$ Dendrophthoe pentandra $\mathrm{b}=$ Scurrula oortiana $\mathrm{c}=$ Macrosolen cochinchinensis $\mathrm{e}=$ Viscum articulatum $\mathrm{d}=$ Lepeostegeres gemmiflorus 


\section{Viscaceae}

Hemiparasit, melekat pada tumbuhan inang dengan haustorium primer tunggal. Batang berbuku-buku dan menggalah. Daun atau daun yang rudimenter berhadapan dan tunggal. Perbungaan aksiler atau terminal, tunggal dan kadang-kadang tersusun dalam tandan atau bulir ataupun mengelompok padat. Bunga monoklamid, uniseksual. Tenda bunga 2 - 4 merus dan saling mengatup. Benang sari sama jumlahnya dan saling berhadapan dengan tenda bunga, epipetalus. Bakal buah tenggelam, 1 lokuler, kepala putik tunggal dan menyerupai puting susu. Buah menyerupai beri. Biji satu yang dilapisi oleh lapisan lekat yang terletak di dalam berkas pengangkutan.

\section{Kunci identifikasi jenis benalu suku Loranthaceae}

Suku Loranthaceae di KR Cibodas terdiri atas 4 jenis. Berikut adalah kunci identifikasi untuk membedakan 4 jenis benalu pada suku Loranthaceae.

1. a. Bunga dengan 1 braktea dan 2 brakteola ......................Macrosolen cochinchinensis

b. Bunga dengan 1 braktea .2

2. a. Mahkota bunga terdiri atas 4 cuping. Buah berbentuk rompong.........Scurrula oortiana

b. Mahkota bunga terdiri atas 5 - 6 cuping.

Buah tidak berbentuk rompong... ... 3

3. a. Mahkota bunga terdiri atas 5 cuping. Buah berbentuk bulat telur...........Dendrophthoe pentandra

b. Mahkota bunga terdiri atas 6 cuping. Buah berbentuk bulat......................Lepeostegeres gemmiflorus

\section{Deskripsi jenis-jenis benalu dari suku Loranthaceae}

\section{Dendrophthoe pentandra (L.) Miq}

Perdu, hemiparasit, agak tegar, bercabang banyak, tinggi 0,5 - 1,5 m. Daun tersebar atau sedikit berhadapan, menjorong, panjang $6-13 \mathrm{~cm}$ dan lebar $1,5-8 \mathrm{~cm}$, pangkal menirus - membaji, ujung tumpul runcing, panjang tangkai daun $5-20 \mathrm{~mm}$. Perbungaan tandan dengan $6-12$ bunga, panjang sumbu perbungaan $10-35 \mathrm{~mm}$. Bunga dengan 1 braktea di pangkal, biseksual, diklamid, kelopak mereduksi; mahkota bunga terdiri atas 5 cuping, dibagian bawah saling berpautan, agak menggelendut, panjang $13-26$ $\mathrm{mm}$, menyempit membentuk leher, bagian ujung menggada, mula-mula hijau kemudian hijau kekuningan sampai kuning orange atau merah orange, panjang tabung $6-12 \mathrm{~mm}$ dan menggenta; benang sari 5 , panjang kepala sari 2 - $5 \mathrm{~mm}$ dan tumpul serta melekat pada bagian pangkal (basifik); putik dengan kepala putik membintul.

Buah bulat telur, panjang mencapai 10 mm dengan lebar $6 \mathrm{~mm}$, bila masak kuning jingga. Berbiji 1, biji ditutupi lapisan lengket. Penyebaran: India sampai Indo Cina, Semenanjung Malaya, Sumatera, Jawa, Kalimantan, Nusa Tenggara dan Filipina. Habitat: Umumnya di hutan hujan atau hutan yang terbuka, di perkebunan-perkebunan dataran rendah namun seringkali terdapat sampai pada ketinggian 1650 m dpl. Kegunaan: Bubur dari bagian daun untuk mengobati luka pedih, bernanah dan infeksi pada kulit. Air rebusan semua bagian tumbuhan bila diminum dapat mengobati hipertensi dan apabila dicampur minuman teh digunakan untuk obat batuk (Valkenburg, 2003).

\section{Scurrula oortiana (Korth.) Dans}

Perdu, ramping, cukup tegar, bagian yang muda ditutupi rambut-rambut bintang yang padat berwarna emas atau coklat merah dan menjadi jarang setelah dewasa. Daun berhadapan, bentuk helaian lonjong sampai bundar telur, panjang 9 - $14 \mathrm{~cm}$ dan lebar 4,5 $6 \mathrm{~cm}$, pangkal daun rompong atau agak menjantung, panjang tangkai daun $3-8 \mathrm{~mm}$. Perbungaan aksiler, tandan dengan $4-12$ bunga, panjang sumbu perbungaan $8-40 \mathrm{~mm}$. Bunga biseksual, diklamid, panjang pedisel 3 $9 \mathrm{~mm}$; braktea berbentuk jorong sampai agak bundar, cembung, membundar, panjang $5-7$ $\mathrm{mm}$, menutupi bakal buah; mahkota bunga ramping, ujung menggada dan runcing, panjang tabung mahkota 10 - $30 \mathrm{~mm}$; panjang kepala sari $2-3 \mathrm{~mm}$. Buah rompong, panjang $11-14$ $\mathrm{mm}$ termasuk panjang tangkai $7-11 \mathrm{~mm}$. Penyebaran: Sumatera dan Jawa. Habitat: Tumbuh di dataran tinggi mulai 1000 - 2050 m dpl. Kegunaan: Belum diketahui. 


\section{Macrosolen cochinchinensis (Lour.) Tiegh}

Perdu, hemiparasit, tegar dan bercabang banyak. Batang muda berbuku-buku dan bersegi empat yang kemudian berubah menjadi menggalah, bertepi ganda atau bersegi empat. Daun berhadapan, menjorong atau membundar telur, panjang 4-16 cm dan lebar $2-7 \mathrm{~cm}$, pangkal membaji sampai rompong, panjang tangkai daun 3-10 mm, ujung runcing sampai meruncing dan kadang-kadang tumpul, pertulangan daun menyirip dengan tulang tengah menonjol dan tulang-tulang lateral yang nyata di kedua permukaan daun.

Perbungaan aksiler, muncul pada ruasruas, majemuk agak memayung atau tandan membulir dengan $2-7$ pasang bunga yang berhadapan, panjang sumbu $5-40 \mathrm{~mm}$. Bunga dengan 1 braktea dan 2 brakteola pada pangkalnya, biseksual, diklamid, panjang pedisel $1-6 \mathrm{~mm}$; mahkota bunga terdiri atas 6 cuping, panjang $8-23 \mathrm{~mm}$, dekat dibagian tengah bersayap, menyudut, kuning kehijauan, bagian leher berwarna gelap dan dibagian atas kuning atau merah, panjang tabung mahkota bunga $5-14 \mathrm{~mm}$ dengan cuping-cuping terkeluk balik; panjang kepala sari 0,5 - $2 \mathrm{~mm}$, runcing, kira-kira setengah sampai sepertiga panjang dari panjang tangkai sari yang bebas. Buah berbentuk bulat, panjang $6-7 \mathrm{~mm}$, bila masak berwarna kuning sampai ungu kecoklatan. Persebaran: Asia bagian selatan dari Himalaya kearah timur sampai Cina bagian selatan dan Indo Cina. Di kawasan Malesiana tersebar mulai dari Semenan-jung Malaysia sampai Nugini. Habitat: Tumbuh di hutanhutan basah dan terbuka serta area yang telah terganggu. Umumnya di dataran rendah dan kadang-kadang dapat mencapai ketinggian sampai $2270 \mathrm{~m}$ dpl.

\section{Lepeostegeres gemmiflorus (Blume) Blume}

Perdu, hemiparasit, tegar dan gundul. Ruas-ruas batang muda bersegi empat. Daun berhadapan, membundar telur, kedua permukaan daun suram, panjang $5-8 \mathrm{~cm}$ dan lebar $2-5 \mathrm{~cm}$, pangkal rompong, panjang tangkai daun $1-2 \mathrm{~cm}$, ujung membundar atau tumpul; pertulangan menyirip dengan tulang tengah menonjol dibagian permukaan bawah dan tulang-tulang lateral yang nyata di kedua permukaan daun.
Perbungaan aksiler, terdapat pada ruasruas, panjang sumbu perbungaan $5 \mathrm{~mm}$ dan lebar $5-7 \mathrm{~mm}$; braktea 7 - 9 pasang, bagian paling dalam yang paling panjang dan melonjong, panjang $14-20 \mathrm{~mm}$, tetap tinggal merapat sesudah antesis; bunga $2-4$ pasang triad yang duduk, panjang pedisel $0,2-0,3$ $\mathrm{mm}$; mahkota bunga terdiri atas 6 cuping, panjang $20-26 \mathrm{~mm}$, secara bertahap melebar kearah atas, ujung tumpul, merah atau orange atau kuning, kadang-kadang dibagian atas kuning kehijauan atau merah padam dibagian ujung, panjang tabung pada bagian yang terbuka $8 \mathrm{~mm}$ dan panjang cuping yang terkeluk balik 7 - $12 \mathrm{~mm}$; panjang kepala sari 1,5 - $2 \mathrm{~mm}$, panjang tangkai sari yang bebas 2 - $5 \mathrm{~mm}$. Buah bulat dan bergaris tengah mencapai $8 \mathrm{~mm}$, bila masak berwarna orange cerah sampai kuning pucat. Persebaran: Jawa bagian barat. Habitat: tumbuh pada ketinggian 200 - 1600 m dpl.

\section{Deskripsi jenis benalu suku Viscaceae}

\section{Viscum articulatum Burm. f}

Tumbuhan ramping, menggantung, bercabang banyak. Batang beruas-ruas, pipih, persegi empat atau bertepi rangkap. Daun rudimenter dan menyerupai braktea kecil. Perbungaan aksiler, pada awalnya mengandung bunga betina tunggal dan kemudian di bawahnya muncul beberapa bunga jantan. Bunga jantan mempunyai perhiasan bunga yang terdiri atas 4 cuping, setiap cuping perhiasan bunga berbentuk segitiga pendek, panjang sampai o,25 mm. Bunga betina dengan cuping perhiasan bunga yang panjangnya sampai 0,5 mm, cuping lebih pendek daripada tabung dan agak tebal. Buah bulat, duduk, halus, putih mengkilap dan bergaris tengah 3 $\mathrm{mm}$. Berbiji satu dan ditutupi oleh lapisan yang lengket. Penyebaran: Dari India sampai Vietnam, Malesiana dan Australia. Habitat: Hutan terbuka atau tertutup mulai dari ketinggian 0 - 1500 m dpl. Kegunaan: Rebusan semua bagian tumbuhan apabila diminum dapat mengobati penyakit bronchitis. Selain itu dapat juga berfungsi sebagai aprodisiak dan neuralgik serta mengobati tumor kulit dan anthritis (Valkenburg, 2003). 


\section{Kesimpulan dan Saran}

\section{Kesimpulan}

Lima jenis benalu (Dendrophthoe pentandra, Scurrula oortiana, Macrosolen cochinchinensis, Lepeostegeres gemmiflorus dan Viscum articulatum) tercatat telah memarasiti 91 jenis (dari 41 suku) tanaman koleksi di Kebun Raya Cibodas. Dua jenis diantaranya, yaitu Dendrophthoe pentandra dan Scurrula oortiana merupakan jenis-jenis benalu yang paling banyak memarasiti tanaman koleksi. Jenis-jenis tanaman koleksi dari suku Moraceae, Myrtaceae dan Rosaceae adalah yang ditemukan banyak diparasiti benalu. Salah satu diantara ketiga suku tersebut yaitu Moraceae dan khususnya pada marga Ficus adalah yang paling banyak jumlah jenisnya telah diparasiti oleh benalu. Intensitas pemarasitan benalu terhadap jenis-jenis tanaman inang diperkirakan terkait dengan tebal atau tipisnya kulit cabang/ranting. Semakin tipis dan lunak kulit cabang/ranting tanaman inang maka semakin banyak jumlah jenis maupun jumlah individu benalu yang memarasitinya.

\section{Saran}

Dari hasil penelitian ini disarankan kepada pengelola Kebun Raya Cibodas untuk lebih mewaspadai keberadaan jenis-jenis benalu parasit, khususnya jenis D. pentandra dan S. oortiana. Tindakan pengendalian dilakukan dengan metode sederhana, yaitu pemangkasan cabang/ranting yang terserang benalu secara dini.

\section{Ucapan Terima Kasih}

Penulis mengucapkan terima kasih khususnya kepada Kepala Puslit Biologi dan Kabid Botani serta Koordinator Sub Kegiatan Penelitian tentang "Valuasi kerusakan ekositem mikro oleh tumbuhan parasit dan upaya pengendaliannya" yang telah menugaskan penulis untuk melakukan penelitian ini. Terima kasih juga kepada Kepala Kebun Raya Cibodas di Jawa Barat dan stafnya yang telah membantu penelitian ini hingga selesai.

\section{Daftar Pustaka}

Backer, C.A. and van den Brink, B. 1965. Flora of Java, vol. 2. Noordhoff, Groningen. The Netherlands.

van Balgooy, M.M.J. 1987. Collecting. In: Vogel (Eds.). Mannual of Herbarium Taxonomy. Theory and Practice. Unesco.

Barlow, B.A. 1967. Loranthaceae. In: Kalkman, C., Kirkup, D.W., Nootebom, H.P., Stevens, P.F., de Wilde, W.J.J.O. (Eds.). Flora Malesiana I (13): 209-401. Rijksherbarium/Hortus Botanicus, The Netherlands.

Danser, B.H. 1930. The Loranthaceae of Nederlands Indies. Bull. de Jardin Botanique. III (XI): 233-519.

Immamudin, H., Suryana, N., Suhatman, A. and Hidayat, A. 2005. An alphabetical list of plant cultivated in the Cibodas Botanic Garden. Cibodas Botanic Garden.

Pitojo, S. 1996. Benalu hortikultura: Pengendalian dan Pemanfaatan. Ungaran: Trubus Agriwidya.

Rugayah, Widjaja, E.A. dan Praptiwi. 2004. Pedoman pengumpulan data keanekaragaman flora. Pusat Penelitian Biologi - LIPI, Bogor.

Sunaryo, Rachman, E. dan Uji, T. 2006. Kerusakan morfologi tumbuhan koleksi Kebun Raya Purwodadi oleh benalu (Loranthaceae dan Viscaceae). Berita Biologi 8 (2): 129-139.

Uji, T., Sunaryo dan Rachman, E. 2006. Keanekaragaman jenis benalu parasit pada tanaman koleksi di Kebun Raya Purwodadi, Jawa Timur. J. Teknologi Lingkungan. 223-231.

Uji, T., Sunaryo dan Rachman, E. 2007. Keanekaragaman jenis benalu parasit pada tanaman koleksi di Kebun Raya Ekakarya, Bali. Berkala Penelitian Hayati 3 (1): 1-6.

van Valkenburg, J.L.C.H. 2003. Dendrophthoe. In: Lemmens, R.H.M.J. and Bunyapraphatsara, N. (Eds.). Medicinal and poisonous plants 3. PROSEA. Backhuys Publisher, Leiden.

van Leeuwen, W.M. 1954. On the biology of some javanese Loranthaceae and the role birds play in their life history. Beaufortia 4 (41): 103207. 